\title{
Rockshelters and the impact of the Laacher See eruption on Late Pleistocene foragers
}

Felix Riede ${ }^{1,{ }^{*}}$, Florian Sauer ${ }^{1} \&$ Christian Hoggard ${ }^{1}$

Predictive modelling has identified rockshelter sites to the north-east of the Laacher See volcano in western Germany. These will be excavated to investigate the impacts of volcanic eruption on Late Pleistocene foragers.

Keywords: Germany, Laacher See volcano, Late Pleistocene, rockshelters

The Laacher See volcano, located in the Eifel volcanic field in western Germany, erupted approximately 13000 years ago, with potentially profound effects on the lifeways of local contemporaneous Final Palaeolithic foragers (Riede 2017). The area immediately surrounding the volcano has been extensively investigated, and numerous archaeological sites are known from beneath the widespread tephra blanket (e.g. Baales 2006). Farther afield, however, the number of excavated sites decreases considerably. To test the hypothesis that the eruption had a detrimental, long-distance effect on foragers, the project 'Apocalypse Then? The Laacher See Volcanic Eruption, Deep Environmental History and Europe's Geo-cultural Heritage' initiated a search for new stratified sites at some distance to the north-east of the volcano.

Our study area is located in the German Federal State of Hesse (Figure 1), for which a legacy dataset of rockshelters is available. This was compiled in the 1990s with the explicit goal of finding new Final Palaeolithic sites comparable to rockshelters around the site-complex of Bettenroder Berg, Lower Saxony, located immediately north of the study area (Grote 1994; Hofbauer 1995). The database contains the locations of more than 700 rockshelters, cliffs, blocks and escarpments. We focus on rockshelters, as they-in contrast to open-air sitesprovide particularly favourable conditions for the preservation of both tephra and traces of human settlement. Using available digital elevation models and the rockshelter database, we created an archaeological predictive model using the weighted-layer overlay approach and a MaxEnt-model for cross-validation (Sauer 2018; Wachtel et al. 2018). Both models were tested on 140 Final Palaeolithic locales in the Central Uplands of Germany, in- and outside of Hessen. Orientation, distance to water and landscape accessibility within a $2 \mathrm{~km}$ radius around individual sites were used as predictor values. The resulting models produced a Kvamme's GAIN value of 0.78 (weighted-layer overlay) and 0.85 (MaxEnt) respectively, with 130 of 786 potential rockshelters located in an area of $>50$ per cent suitability. All sites were assessed in relation to their proximity to known occurrences of Laacher See tephra (Riede et al. 2011).

1 Laboratory for Past Disaster Science, Department of Archaeology and Heritage Studies, Aarhus University, Moesgärd Allé 20, 8270 Højbjerg, Denmark

* Author for correspondence (Email: friede@cas.au.dk)

(C) Antiquity Publications Ltd, 2018 ANTIQUITY 92 365, e2 (2018): 1-6 
These predictions were used to select sites for two survey campaigns in 2017 and 2018, with the goal of finding suitable locations for excavation. Eighty locations were visited, and seven candidate

A

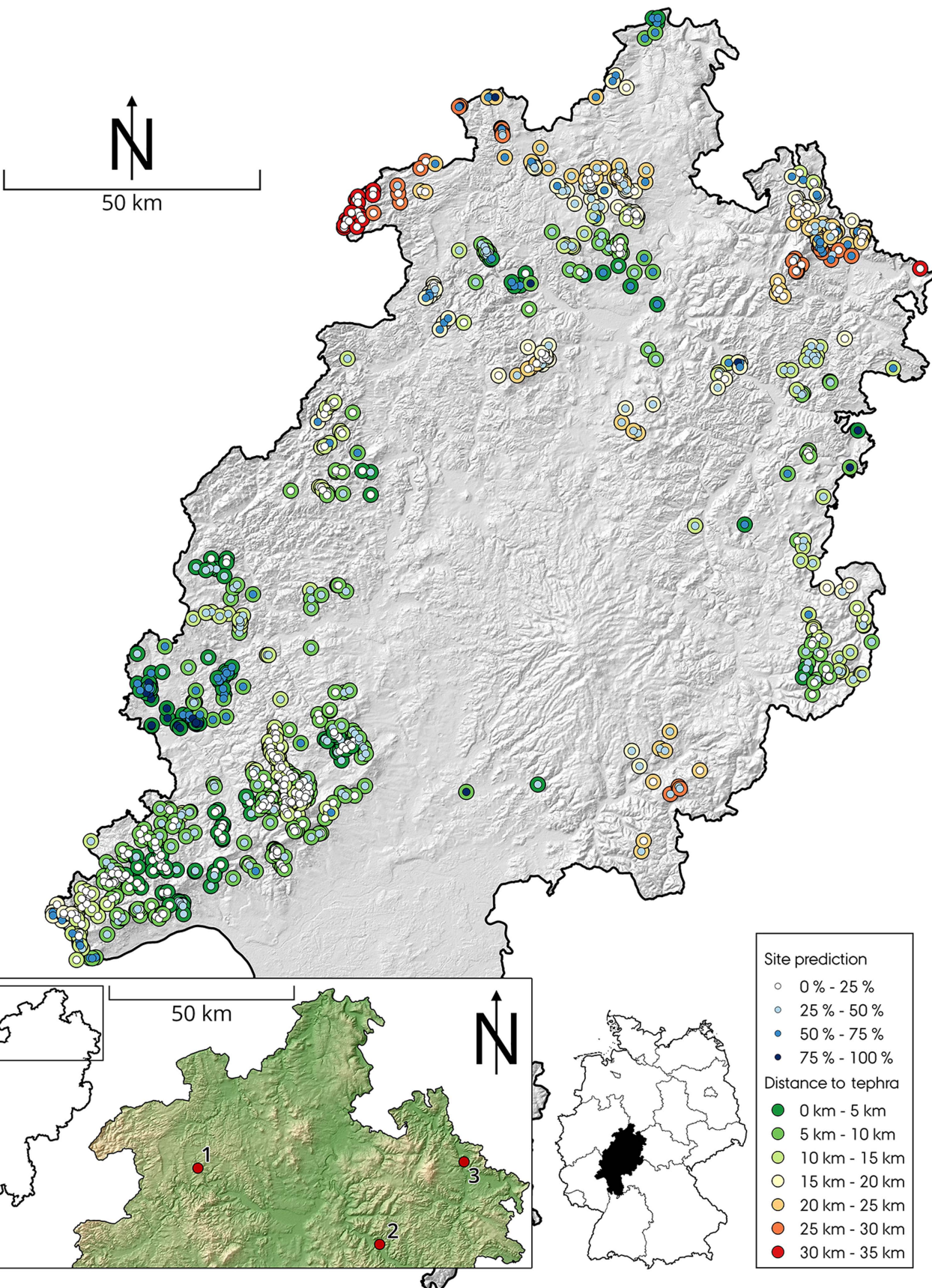

Figure 1. Predictive map for Final Palaeolithic rockshelter sites in the federal State of Hesse (A) and our focus area (B), with 1) Alraft I/II; 2) Baumbach; 3) Wetterstein (map by F. Sauer, based on DEM from European Environment Agency (2013) \& Bundesamt für Kartografie).

(C) Antiquity Publications Ltd, 2018 
sites in the limestone regions of northern Hesse were identified. Four of these locations will be subject to subsequent keyhole excavations (for further details, see Sauer et al. 2018).

\section{Alraft I and II}

Several escarpments are situated near the hamlet of Alraft, on the eastern banks of the Werbe creek. The first lies at the southern entrance of Alraft in a tributary valley, and is oriented to the west and south. At approximately five metres above the valley bottom, the location provides various overhangs and caves, most of which are almost entirely filled with sediment (Figure 2). At the western entrance of Alraft lies a second shelter, facing south-west (Figure 3). Both shelters are promising, as they show strong similarities with the site-complex of Bettenroder Berg.

\section{Baumbach}

The two closely adjacent rockshelters near Baumbach are located in the Fulda River Valley, and are both part of one larger geological feature, which protrudes into the valley bottom at the eastern foothills of the valley and faces to the east and south-east (Figure 4). Although the shelters are relatively shallow, they contain substantial sediment mounds with potentially Late Pleistocene deposits. The floodplain context along the Fulda River and the locale's orientation are similar to other known Final Palaeolithic sites.

\section{Wetterstein}

The Wetterstein is a limestone rock needle overlooking the Werra River Valley, near the hamlet of Kleinvach (Figure 5). At the base of this approximately $25 \mathrm{~m}$-tall feature lies a rockshelter, covering $45-50 \mathrm{~m}^{2}$. It opens towards the south and overlooks the Werra

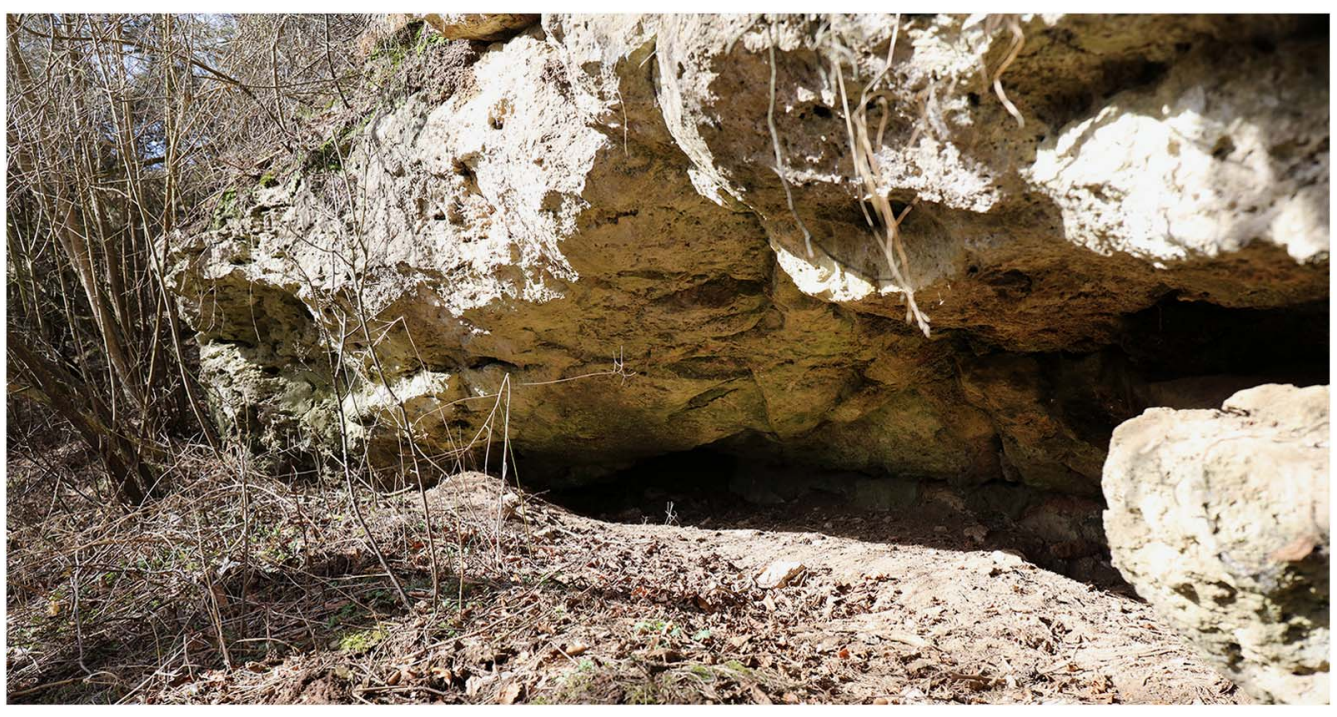

Figure 2. Alraft I with several adjacent rockshelters (photograph by F. Sauer).

(C) Antiquity Publications Ltd, 2018 


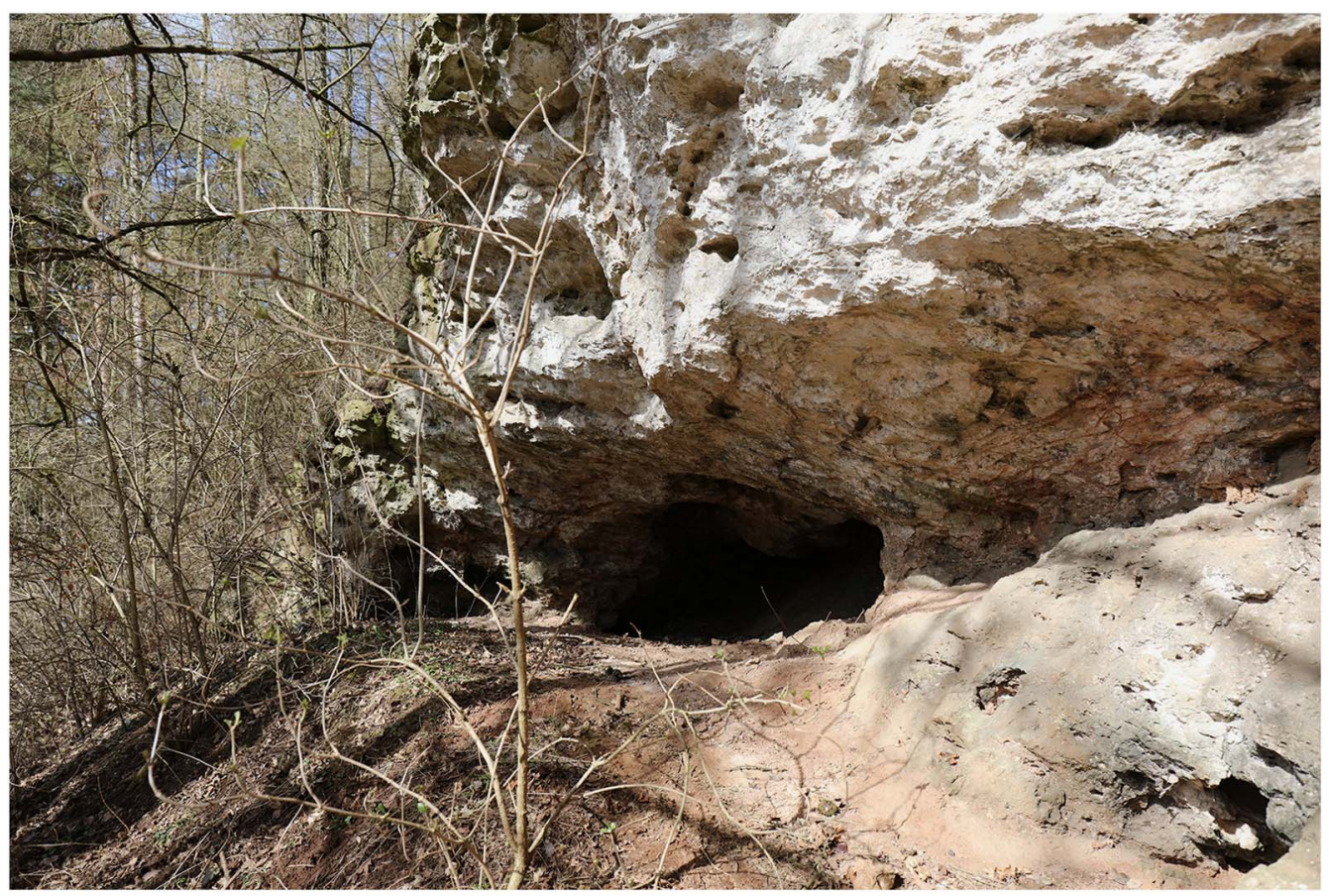

Figure 3. Alraft II (photograph by F. Sauer).

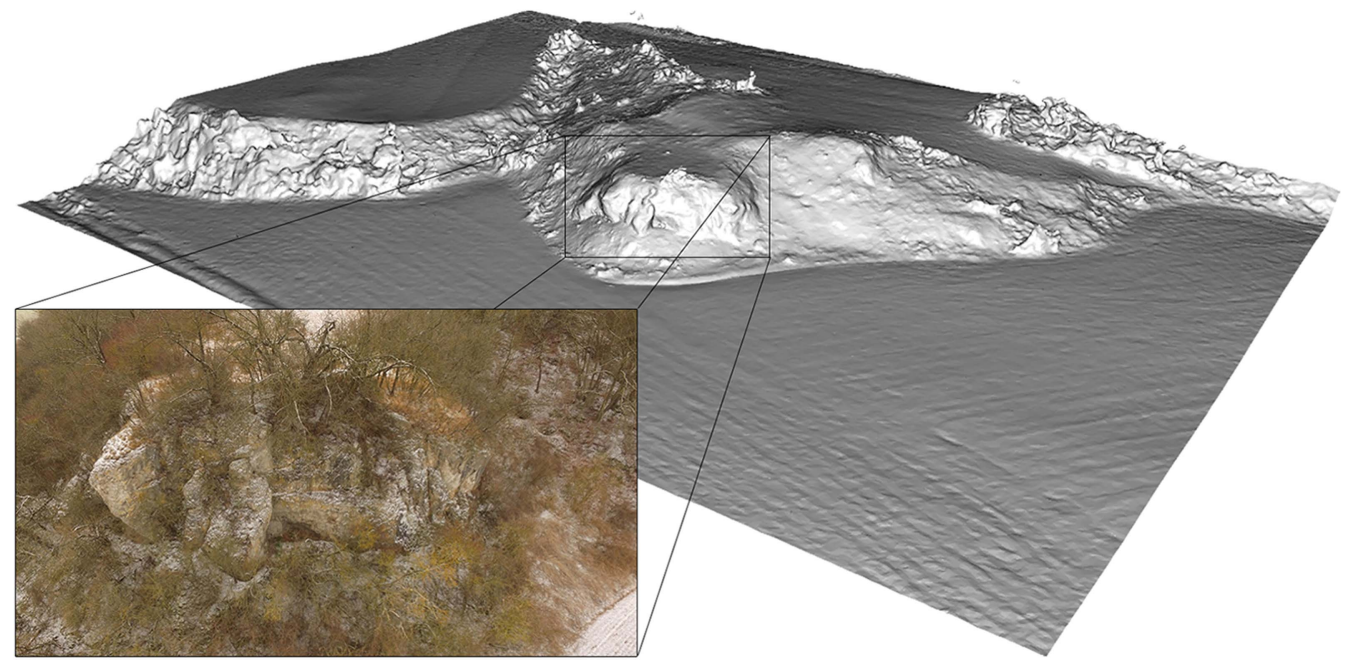

Figure 4. Baumbach, Alheim (fgure by F. Sauer).

floodplain, some $10 \mathrm{~m}$ below the overhang. The Wetterstein is a prominent feature in the landscape, not least due to the white colour of the limestone.

If successful, excavation at these four sites will significantly expand our limited knowledge concerning Final Palaeolithic settlement in the Central Uplands and the reaction of local (C) Antiquity Publications Ltd, 2018 


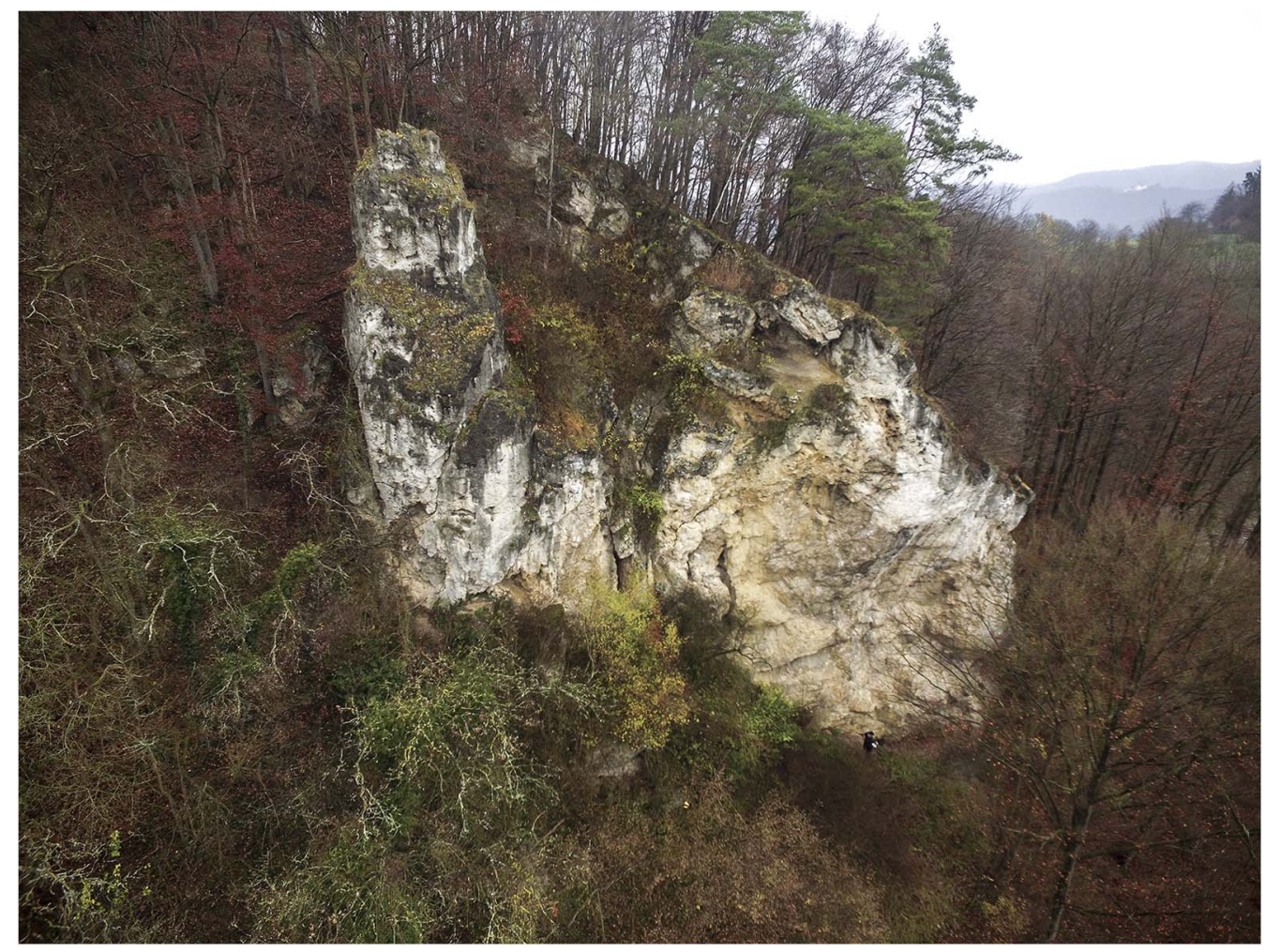

Figure 5. The majestic Wetterstein overlooking the Werra River (photograph by F. Sauer).

foragers to the Laacher See eruption, its tephra fallout and associated climatic and environmental impacts.

\section{Acknowledgements}

The authors wish to thank the Independent Research Fund Denmark (\#6107-00059B) for funding.

\section{References}

BaAles, M. 2006. Final Palaeolithic environment and archaeology in the central Rhineland (Rhineland-Palatinate, western Germany): conclusions of the last 15 years of research. Anthropologie 110: 418-44. https://doi.org/10.1016/j.anthro.2006.06.009

European Environment Agency. 2013. Digital elevation model over Europe (EU-DEM) 2000. Available at:

https://www.eea.europa.eu/data-and-maps/data/ eu-dem (accessed 20 September 2018).
Grote, K. (ed.). 1994. Die Abris im südlichen Leinebergland bei Göttingen. Archäologische Befunde zum Leben unter Felsschutzdächern in urgeschichtlicher Zeit. Oldenburg: Isensee.

Hofbauer, H. 1995. Abri-Kataster von Hessen: Ein Vorbericht. Berichte der Kommission für archäologische Landesforschung in Hessen 3: 99-105.

RIEDE, F. 2017. Splendid isolation. The eruption of the Laacher See volcano and southern Scandinavian Late Glacial hunter-gatherers. Aarhus: Aarhus University Press. 
Riede, F., O. Bazely, A.J. Newton \& C.S. Lane. 2011. A Laacher See eruption supplement to tephrabase: investigating distal tephra fallout dynamics. Quaternary International 246: 134-44.

http//:dx.doi: 10.1016/j.quaint.2011.06.029

SAUER, F. 2018. Spätpaläolithische

Landnutzungsmuster in Bayern. Erlangen \& Nürnberg: FAU Erlangen-Nürnberg.

Sauer, F., D. Stotte \& F. Reide. 2018. Search for new final Palaeolithic rock shelter sites in the Federal State of Hesse. Journal of Archaeological Science: Reports 22: 168-78.

https://doi.org/10.1016/j.jasrep.2018.09.021
Wachtel, I., R. Zidon, S. Garti \& G. ShelachLAVI. 2018. Predictive modeling for archaeological site locations: comparing logistic regression and maximal entropy in north Israel and north-east China. Journal of Archaeological Science 92: 28-36.

https://doi.org/10.1016/j.jas.2018.02.001

(C) Antiquity Publications Ltd, 2018 